The subjects taught during the Colonial Courses are as follows : Hygiène, Devoir colonial, Base des langues bantoues, Aperçu général géographique et politique, Histoire: a) de Belgique, b) du Congo, Organisation politique au Congo Belge, Institutions belges de Belgique, Etat civil, Régime religieux, Législation foncière, Législation sociale, Principes généraux coloniaux et Ethnographie.

The diplomas and certificates of those who successfully pass the examination following the Colonial Course, showing the scholastic standard they have reached in their own countries, are then studied by a special 'Commission' set up by the Colonial Minister and this 'Commission' decides as to the grade of school in the Congo which the missionary is qualified to teach and for which subsidies will be granted. The representative in Belgium of the Protestant Missions in the Congo has been made a member of this 'Commission' and the Government acts through him on behalf of the Protestant missionaries seeking qualification.

Missionaries who were in the Congo prior to I January 1930 and who have been given a satisfactory 'Attestation' by a State inspector as to their knowledge of French and ability to teach, need only come to Belgium for three months and make contact with Belgian schools. Those who were in the Congo prior to I January 1945 and who have a similar 'Attestation' need only come for six months. These need only take those subjects of the Colonial Course which deal with Belgium and their attendance at an 'école normale' is reduced to three months.

Different courses of study are organized for medical missionaries and include a course of Tropical Medicine.

Over 900 Protestant missionaries of Congo missionary societies have studied in Belgium for various periods during the past five years.

(communicated by the Rev. H. W. Wakelin Coxill)

\title{
Margaret Wrong Prize
}

IN the competition for I950, which was open to competitors from Southern Sudan, Somaliland, Uganda, Tanganyika, Zanzibar, and the Belgian Congo, the silver medal and prize of fs was awarded to Gabriel-Adrien Ngbongbo of Stanleyville for a novel written in French and entitled Abunawazi le méchant. 